\title{
A Role for Adenosine Deaminase in
}

\section{Human Monocyte Maturation}

\author{
Dina Fischer, Martin B. Van der Weyden, Ralph Snyderman, and \\ William N. Kelley \\ From the Division of Rheumatic and Genetic Diseases, Departments of \\ Medicine, Microbiology, Immunology, and Biochemistry, Duke University \\ Medical Center, Durham, North Carolina 27710
}

A в S T R A C T The occurrence of a deficiency of adenosine deaminase (ADA) activity in some patients with severe combined immunodeficiency suggests a possible relationship between the activity of ADA and the aberration of the immune system. To help delineate the function of ADA in the immune response we have examined its role in monocyte maturation.

When incubated in vitro, peripheral blood monocytes transformed, within 3 days, to macrophages as assessed by phase-contrast microscopy and an increase in the specific activity of the lysosomal enzyme acid phosphatase. The specific activity of ADA increased as much as ninefold, reaching a peak after the 1st day in culture, while the activities of other enzymes involved in the purine salvage pathway were not altered. Sucrose density ultracentrifugation of extracts prepared immediately after the isolation of monocytes revealed the presence of two forms of ADA with molecular weights of approximately 30,000 and 110,000 . The increase in ADA specific activity during monocyte cultivation correlated with an increase in the activity of the smaller molecular species. A specific inhibitor of ADA, erythro9-(2-hydroxy-3-nonyl)adenine, prevented the increase in acid phosphatase activity, as well as the morphological changes associated with the monocyte maturation.

These data suggest a role for ADA in monocyte to

This work was presented in part at the National Meeting of the American Federation for Clinical Research, Atlantic City, N. J., May 1975. Clin. Res. 23: 289A. (Abstr.)

Dr. Snyderman is a Howard Hughes Medical Investigator. Dr. Kelley's present address is: Department of Medicine, University of Michigan School of Medicine, Ann Arbor, Mich. Dr. Van der Weyden's present address is: Department of Medicine AH, Monash University, Clayton, Victoria, 3168-Australia.

Received for publication 17 November 1975 and in revised form 12 March 1976. macrophage maturation. In view of the central role of macrophages in immune function, this observation may relate to the association of combined immunodeficiency and a deficiency of this enzyme.

\section{INTRODUCTION}

A deficiency of the enzyme adenosine deaminase (adenosine aminohydrolase, EC 3.5.4.4, ADA) ${ }^{1}$ has been found in the erythrocytes from a group of patients with severe combined immunodeficiency $(1,2)$. Since a deficiency of this enzyme has not been found in the thousands of normal individuals screened for genetic purposes (3), this suggests a causal relationship between the lack of ADA activity and an aberration of the immune system $(1,4)$.

ADA catalyzes the irreversible deamination of adenosine to produce inosine and ammonia. This is an essential step in the adenosine cycle, which as a part of the purine salvage pathway enables the efficient reutilization (5), and detoxification of adenosine $(6,7)$. An understanding of the function of ADA in cells involved in the immune response may clarify the relationship between a deficiency in this enzyme and the aberration of the immune system.

The involvement of the macrophage and its precursor, the monocyte (8), in the normal immune response is well established $(9,10)$. The monocyte normally comprises $3-7 \%$ of the total circulating leukocytes and has a half-life in the circulation of about $8 \mathrm{~h}$ (11). In a response to inflammatory stimuli, monocytes migrate through capillary walls and enter the tissues where they may mature in size and complexity and become macrophages $(12,13)$. The macrophages function as effector

\footnotetext{
1 Abbreviations used in this paper: ADA, adenosine deaminase ; EHNA, erythro-9-(2-hydroxy-3-nonyl)adenine ; $s_{30, w}$, sedimentation coefficient.
} 



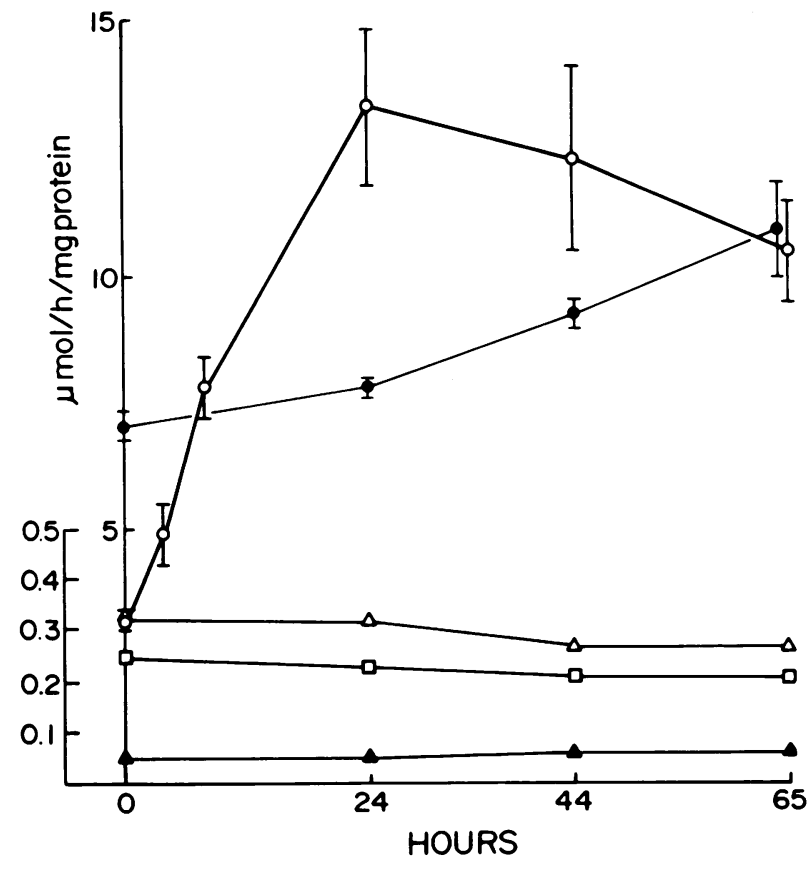

Figure 2 ADA activity in cultured monocytes. The changes $( \pm \mathrm{SEM})$ in ADA specific activity $(O)$ in monocytes during the first 3 days in culture were compared to the specific activities of acid phosphatase ( $\bullet$ ), adenine phosphoribosyltransferase $(\Delta)$, hypoxanthine-guanine phosphoribosyltransferase $(\square)$, and adenosine kinase $(\boldsymbol{\Delta})$. (Note different ordinates, the ADA and acid phosphatase activities demonstrated on the larger scale, the other activities on the smaller scale.)

cells of the immune system by phagocytizing and degrading material recognized as foreign $(10,14)$, and in the processing of antigens $(9,15)$. Thus, these cells play an important role in both cellular and humoral immune responses. Considering the importance of macrophage function in immune responses, we examined the activity of ADA in human monocytes during their maturation to macrophages in vitro.

\section{METHODS}

Materials. ADA inhibitor erythro-9-(2-hydroxy-3-nonyl)adenine (EHNA) was a generous gift of Dr. Gertrude B. Elion, Wellcome Research Laboratories, Burroughs Wellcome Co., Research Triangle Park, N. C.

Radioisotopes. $\left[4,5-{ }^{3} \mathrm{H}\right]$ leucine $(64 \mathrm{Ci} / \mathrm{mM}),\left[8-{ }^{14} \mathrm{C}\right] \mathrm{hy}-$ poxanthine $(51.2 \mathrm{mCi} / \mathrm{mM}),\left[8-{ }^{14} \mathrm{C}\right]$ adenine $(6.53 \mathrm{mCi} /$ $\mathrm{mM})$, and $\left[8-^{14} \mathrm{C}\right]$ adenosine $(50.4 \mathrm{mCi} / \mathrm{mM})$ were obtained from New England Nuclear, Boston, Mass. The radioactive adenosine, hypoxanthine, and adenine were diluted to the appropriate specific activity with the nonradioactive compound.
TABLE I

Effect of Mixing Monocyte and Macrophage Extracts on $A D A$ Activity

\begin{tabular}{lc}
\hline \multicolumn{1}{c}{ Extract } & ADA \\
\hline & $n$ mol $/ h$ \\
Monocyte & 96 \\
Macrophage & 363 \\
Mixed & 432
\end{tabular}

Monocytes were suspended in $10 \mathrm{mM}$ Tris- $\mathrm{HCl}$ buffer $\mathrm{pH} 7.4$ $\left(10^{6}\right.$ cells $\left./ 400 \mu \mathrm{l}\right)$. After freeze-thawing three times in liquid nitrogen, supernate from $6,000 \mathrm{~g}$ centrifugation was used for measuring ADA activity. Monocyte extract, processed immediately after isolation, and macrophage extract, processed after $72 \mathrm{~h}$ in culture, were mixed with equal volumes of Tris buffer, and the activities measured in the individual extracts were compared to the activity in the two extracts mixed in equal volumes. The experiment was repeated three times with similar results.

Monocytes isolation. Monocytes were isolated from venous blood of normal volunteers using the method of Bennett and Cohn (16) with the modifications of Brodersen and Burns (17). Leukocytes from $200-250 \mathrm{ml}$ of blood were collected after the erythrocytes were sedimented with $3 \%$ high molecular weight dextran (T-500; Pharmacia Fine Chemicals, Inc., Piscataway, N. J.). The cells were suspended in $27 \%$ bovine albumin (Cohn fraction V; Sigma Chemical Co., St. Louis, Mo.) in $0.02 \mathrm{M}$ phosphate-buffered isotonic saline $\mathrm{pH} 7.4$ and centrifuged at 2,400 $g$ at $12^{\circ} \mathrm{C}$ for $36 \mathrm{~min}$. Of the monocytes present initially, 30 $75 \%$ were recovered in the pellicle of cells formed at the surface. These preparations also contained $15-40 \%$ lymphocytes, as judged morphologically using phase-contrast microscopy. When higher purity of monocytes was required, the cells collected from the albumin flotation were washed and suspended in culture media which consisted of RPMI 1640 (Grand Island Biological Co., Grand Island, N. Y.) containing $30 \%$ heat-inactivated $\left(56^{\circ} \mathrm{C}\right.$ for $\left.30 \mathrm{~min}\right)$ fetal calf serum (Grand Island Biological Co.) and $0.1 \mathrm{mg}$ erythromycin. This culture medium was used in all experiments unless otherwise specified. The suspended cells were incubated in Optilux tissue culture dishes (Falcon Plastics, Division of BioQuest, Oxnard, Calif., 3003) at $37^{\circ} \mathrm{C}$ with a constant $5 \% \quad \mathrm{CO}_{2}, 95 \%$ humidified air environment. After $2 \mathrm{~h}$ the unattached cells, which consisted mainly of lymphocytes, were removed by washing with the culture medium. The adherent monocytes were suspended in reconstituted culture medium by gentle scraping with a rubber policeman. The suspensions obtained contained less than $10 \%$ lymphocytes.

Total cell counts were performed in a hemocytometer after staining with Türk's stain, and viability of cells was determined by dye exclusion ( $0.1 \%$ trypan blue).

The cell suspension was diluted with the culture medium to a density of $10^{\circ}$ monocytes $/ \mathrm{ml}$ and incubated in $1-\mathrm{ml}$

FIGURE 1 Human monocyte cultured in vitro. Monocytes were isolated by centrifugation of leukocytes in a dense albumin gradient, and phase-contrast micrographs of unfixed preparations made $(\times 2,000)$. (A) Before cultivation. The nucleus is indented and a few small granules distributed in the cytoplasm. (B) After $72 \mathrm{~h}$ in culture. The nucleus is eccentrically located, and the enlarged cytoplasm is filled with large phase-dense lysosomal granules. 
TABLE II

ADA Activity in Monocytes Cultured in the Absence of Fetal Calf Serum

\begin{tabular}{crc}
\hline \multirow{2}{*}{$\begin{array}{c}\text { Incubation } \\
\text { time }\end{array}$} & \multicolumn{2}{c}{$\mathrm{ADA}, \mu$ mol $/ \mathrm{h} / \mathrm{mg}$ protein } \\
\cline { 3 - 3 } & No FCS & $30 \%$ FCS \\
\hline$h$ & & \\
0 & 3.60 & 3.64 \\
8 & 6.34 & 10.49 \\
20 & 12.33 & 12.77 \\
44 & 12.32 & 14.56
\end{tabular}

Monocytes were cultured in RPMI 1640 with and without fetal calf serum (FCS). The activity of ADA was measured in the cell extracts (obtained as described in Table I). The experiment was repeated three times with similar results.

aliquots in polypropylene tubes (Falcon Plastics, 2006) at $37^{\circ} \mathrm{C}$ in $5 \% \mathrm{CO}_{2}, 95 \%$ humidified air environment.

Cultures of monocytes obtained by albumin flotations were compared to those of highly purified monocytes obtained after cell adherence, and the results did not differ significantly. Therefore the adherence purification step was used only when the albumin flotation preparation was contaminated by $30 \%$ or more lymphocytes and for all experiments which were performed to study the molecular forms of the enzyme.

Cell processing. After various periods of incubation in vitro, cells were processed for morphological and biochemical studies as described below.

Cell suspensions were centrifuged at $4^{\circ} \mathrm{C}$ at $600 \mathrm{~g}$ for $10 \mathrm{~min}$ and resuspended in a small volume of culture medium. A drop from the concentrated suspension was used for morphological studies by phase-contrast microscopy using a Zeiss Ortholux microscope (Carl Zeiss, Inc., New York). The shape and position of the nucleus, the nuclear to cytoplasmic ratio, and cytoplasmic inclusions were recorded.

For biochemical assays the cells were washed three times with phosphate-buffered saline; centrifugation was carried out at $4^{\circ} \mathrm{C}$ at $600 \mathrm{~g}$ for $10 \mathrm{~min}$. The cell pellets, which were stored at $-70^{\circ} \mathrm{C}$ for $24-72 \mathrm{~h}$, were suspended in $400 \mu \mathrm{l}$ ice-cold $0.01 \mathrm{M}$ Tris- $\mathrm{HCl} \mathrm{pH} 7.4$ and lysed by freezing and thawing six times in liquid nitrogen. The suspension was centrifuged at $4^{\circ} \mathrm{C}$ at $6,600 \mathrm{~g}$ for $15 \mathrm{~min}$, and the enzymatic activities were assayed in the supernate. Storing the cell pellets at $-70^{\circ} \mathrm{C}$ did not affect the ADA activity and improved the extraction of the acid phosphatase.

Enzy'me assay's. ADA was assayed by the conversion of $\left[8-{ }^{14} \mathrm{C}\right]$ adenosine to $\left[8-{ }^{14} \mathrm{C}\right]$ inosine as previously described (18). ADA activity was linear with time and with protein concentration in both monocyte and macrophage extracts. The stability of the enzyme was studied in extracts of both cells, and neither was affected by incubation at $37^{\circ} \mathrm{C}$ for $2 \mathrm{~h}$. After dialysis, the activity of ADA in the extracts did not change significantly. Hypoxanthine-guanine phosphoribosyltransferase (EC 2.4.2.8) and adenine phosphoribosyltransferase (EC 2.4.2.7) were assayed by a radiochemical method as previously described (19). The radiochemical method used for the adenosine kinase (EC 2.7.1.20) assay $^{2}$ was a

\footnotetext{
${ }^{2}$ Van der Weyden, M. B., and W. N. Kelley. 1975. Mechanism of inhibition of human adenosine deaminase by erythro9-(2-hydroxy-3-nonyl) adenine and coformycin. Manuscript in preparation.
}

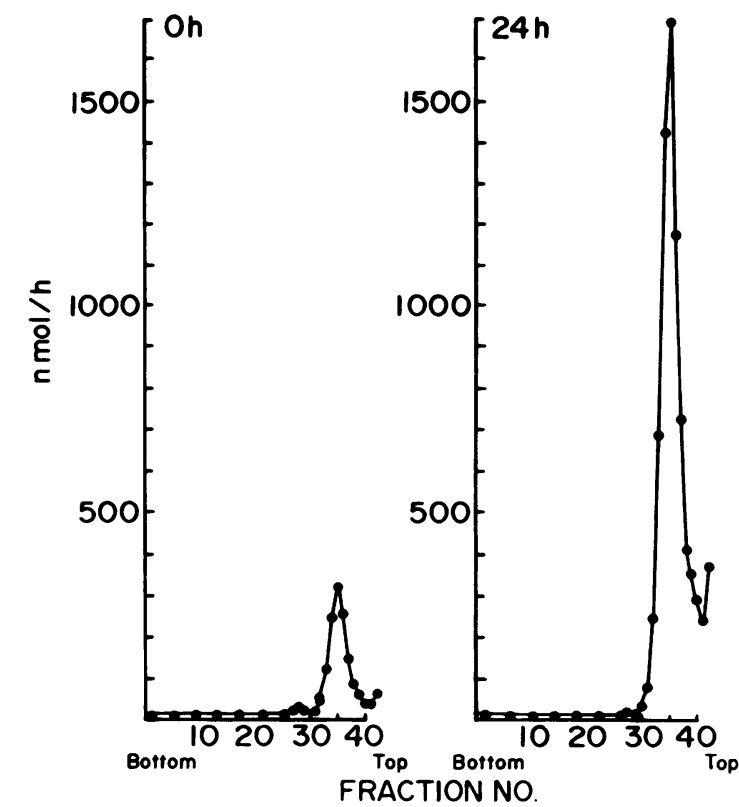

FIGLRE 3 The molecular forms of ADA in cultured monocytes. Distribution of ADA activity after sucrose density gradient ultracentrifugation of extract from monocytes before $(0 \mathrm{~h})$ and after $(24 \mathrm{~h})$ cultivation.

modification of a spectrophotometric technique (20). Acid phosphatase (EC 3.1.3.2) was assayed in the extracts before centrifugation, with p-nitropheny'l phosphate as a substrate (21), and was demonstrated cytochemically by the azo dye method (22).

Protein determination. Protein was determined using the method of Lowry et al. (23) with bovine serum albumin as standard. Distortions of measurements by Tris buffer were corrected as previously described (24).

Sucrose gradients. $10-28.2 \%$ isokinetic sucrose gradients

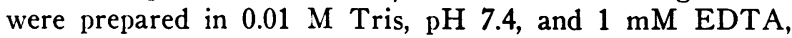

'TABLE III

The Effect of Puromycin on the Enhancement of $A D A$ Activity during Cultivation of Monocytes

\begin{tabular}{|c|c|c|c|c|}
\hline & \multicolumn{2}{|c|}{ Control } & \multicolumn{2}{|c|}{ Puromycin, $3 \mu \mathrm{M}$} \\
\hline & $2 \mathrm{~h}$ & $20 \mathrm{~h}$ & $2 \mathrm{~h}$ & $20 \mathrm{~h}$ \\
\hline $\begin{array}{c}{\left[{ }^{3} \mathrm{H}\right] \text { Leu incorporation, }} \\
\mathrm{cpm} / 2 \mathrm{~h} / 10^{5} \text { cells }\end{array}$ & & 1,090 & & 360 \\
\hline ADA, $\mu m o l / h / m g$ protein & 2.1 & 11.5 & 2.2 & 3.2 \\
\hline
\end{tabular}

Puromycin was added to the cultures at time 0 , and $\left[{ }^{3} \mathrm{H}\right]$ leu $(5 \mu \mathrm{Ci})$ was added $2 \mathrm{~h}$ before the cells were washed. The washed cells were suspended in $10 \mathrm{mM}$ Tris- $\mathrm{HCl} \mathrm{pH}$ 7.4. After freeze-thawing three times, the nucleic acids and proteins were precipitated with equal volume of cold $10 \%$ TCA. The precipitates were collected on glass fiber filters, washed, dried, and the radioactivity determined. ADA activity was measured in extracts from cells which were not labeled with the $\left[{ }^{3} \mathrm{H}\right]$ leu. Similar results were obtained from two different cultures. 
as described previously (25). Samples $(200 \mu 1)$ of cell extracts and standards were layered on the gradients and then centrifuged at $40,000 \mathrm{rpm}$ for $15 \mathrm{~h}$ at $4^{\circ} \mathrm{C}$ in a Spinco SW41 rotor using a Beckman L5-50 ultracentrifuge (Beckman Instruments, Inc., Spinco Div., Palo Alto, Calif.). In the presence of $0.1 \%$ bovine albumin in the extracts, the distribution of the molecular forms did not change and the recovery of the enzyme activity from the gradients increased from $30-40$ to $100 \%$. 255- $\mu$ l fractions were collected with a Gilson microfractionator (Gilson Medical Electronics, Inc., Middleton, Wis.). Sedimentation coefficients $\left(s_{20, w}\right)$ were calculated on the basis of a linear relationship of the $\boldsymbol{s}_{20}$, w to the distance migrated in the sucrose gradient (26). Bovine serum albumin $\left(s_{20, w}, 4.3\right)$, human hemoglobin $\left(s_{20, w}\right.$, $4.1)$, and catalase $\left(s_{20, w}, 11.3\right)$ were used as standards for calculations.

Protein synthesis. Protein synthesis was estimated in the presence and absence of puromycin. $5 \mu \mathrm{Ci}$ of $\left[{ }^{3} \mathrm{H}\right]$ leucine was added to a 1-ml culture and after a 2 -h labeling period the cells were washed three times with phosphate-buffered saline and resuspended in $0.01 \mathrm{M}$ Tris- $\mathrm{HCl} \mathrm{pH}$ 7.4. After freeze-thawing three times in liquid nitrogen, an equal volume of $10 \%$ TCA was added to the lysates at $4^{\circ} \mathrm{C}$ for 30 $\min$ to precipitate nucleic acids and proteins. The precipitates were collected on glass fiber filters (Reeve Angel no. 934-Ah, $2.4 \mathrm{~cm}$ diameter; Whatman, Inc., Clifton, N. J.) and washed four times with $5 \mathrm{ml}$ of ice-cold $5 \%$ TCA and twice with $5 \mathrm{ml}$ of ice-cold $95 \%$ ethanol. The filters were dried and placed in a toluene-based scintillation fluid. Radioactivity was measured in a Packard Tri-Carb liquid scintillation counter (Packard Instrument Co., Inc., Downers Grove, IIl.) at $14.5 \%$ efficiency. To inhibit protein synthesis, puromycin was added at time 0 at a concentration of $3 \mu \mathrm{M}$. This concentration was found to inhibit the incorporation of radioactive leucine into acid-insoluble material to $40 \%$ of control values, while the number of nonviable cells after $20 \mathrm{~h}$ was not significantly greater than that of the control.

\section{RESULTS}

Maturation of monocytes in vitro. The monocyte morphology after the purification process resembled that of monocytes in freshly drawn blood. The centrally located indented nucleus occupied most of the cell. The
TABLE IV

Specificity of Inhibition of $A D A$ by $E H N A$

\begin{tabular}{|c|c|c|}
\hline & \multicolumn{2}{|c|}{$\mu m o l / h / m g$ protein } \\
\hline & $\begin{array}{c}\text { No } \\
\text { inhibitor }\end{array}$ & $\begin{array}{l}\text { EHNA } \\
(0.3 \mathrm{mM})\end{array}$ \\
\hline Adenosine kinase* & 0.051 & 0.053 \\
\hline APRT & 0.386 & 0.369 \\
\hline HGPRT & 0.270 & 0.267 \\
\hline Acid phosphatase & 6.000 & 6.250 \\
\hline ADA & 3.791 & $<0.1$ \\
\hline
\end{tabular}

* An extract of monocytes was assayed for the specific activities of adenosine kinase, adenine phosphoribosyltransferase, (APRT), hypoxanthine-guanine phosphoribosyltransferase (HGPRT), acid phosphatase, and ADA in the presence and absence of EHNA. The inhibitor was added immediately before the enzymes were assayed. The experiment was repeated three times with reproducible results.

cytoplasm contained occasional vacuoles and only a few phase-dense granules (Fig. 1A). By $8 \mathrm{~h}$ in culture, the cells had undergone morphological changes which became more prominent after $24 \mathrm{~h}$. The nuclei became eccentrically located and the cytoplasm more abundant and filled with variable numbers of highly refractile lipid droplets and increasing numbers of phase-dense lysosomal (16) granules. By $72 \mathrm{~h}$ the monocytes acquired the typical morphology of macrophages, with the above changes being more accentuated and uniformly present (Fig. 1B).

The increase in the number and size of lysosomal granules was accompanied by an increase in the cytochemically demonstrable activity of the lysosomal enzyme acid phosphatase. Cells stained by the azo dye method after $24 \mathrm{~h}$ in culture showed little or no reaction product, while after $48 \mathrm{~h}$ of cultivation many

TABLE V

Effect of Adenosine on Monocytes in Culture

\begin{tabular}{|c|c|c|c|c|c|}
\hline & \multirow[b]{2}{*}{ Control } & \multirow[b]{2}{*}{$\begin{array}{l}\text { Adenosine } \\
\text { (1 mM) }\end{array}$} & \multicolumn{3}{|c|}{ EHNA $(75 \mu \mathrm{M})$} \\
\hline & & & & $\begin{array}{l}\text { Adenosine } \\
(0.1 \mathrm{mM})\end{array}$ & $\begin{array}{l}\text { Adenosine } \\
(1 \mathrm{mM})\end{array}$ \\
\hline \multicolumn{6}{|c|}{ Cell number after $72 \mathrm{~h}$} \\
\hline Total, $\times 10^{6}$ & 1.1 & 0.87 & 0.7 & 0.5 & 0.6 \\
\hline Nonviable, \% & 5 & 2 & 28 & 48 & 91 \\
\hline \multicolumn{6}{|c|}{ Acid phosphatase, $\mu \mathrm{mol} / \mathrm{h} / \mathrm{mg}$ protein } \\
\hline $\mathbf{0 ~ h}$ & $6.5 \pm 0.34$ & $6.4 \pm 0.14$ & $6.4 \pm 0.63$ & $一^{*}$ & - \\
\hline $72 \mathrm{~h}$ & $9.5 \pm 0.22$ & $9.8 \pm 1.26$ & $6.8 \pm 0.59$ & - & - \\
\hline
\end{tabular}

Monocytes isolated by albumin flotation were cultured in the presence and absence of adenosine and/or an ADA inhibitor (EHNA). The effect of adenosine on the cells was evaluated by cell viability on the 3rd day in culture (trypan blue exclusion) and the increase in specific activity of acid phosphatase ( \pm SEM).

* Specific activity inaccurate in the presence of high percentage of dead cells. 


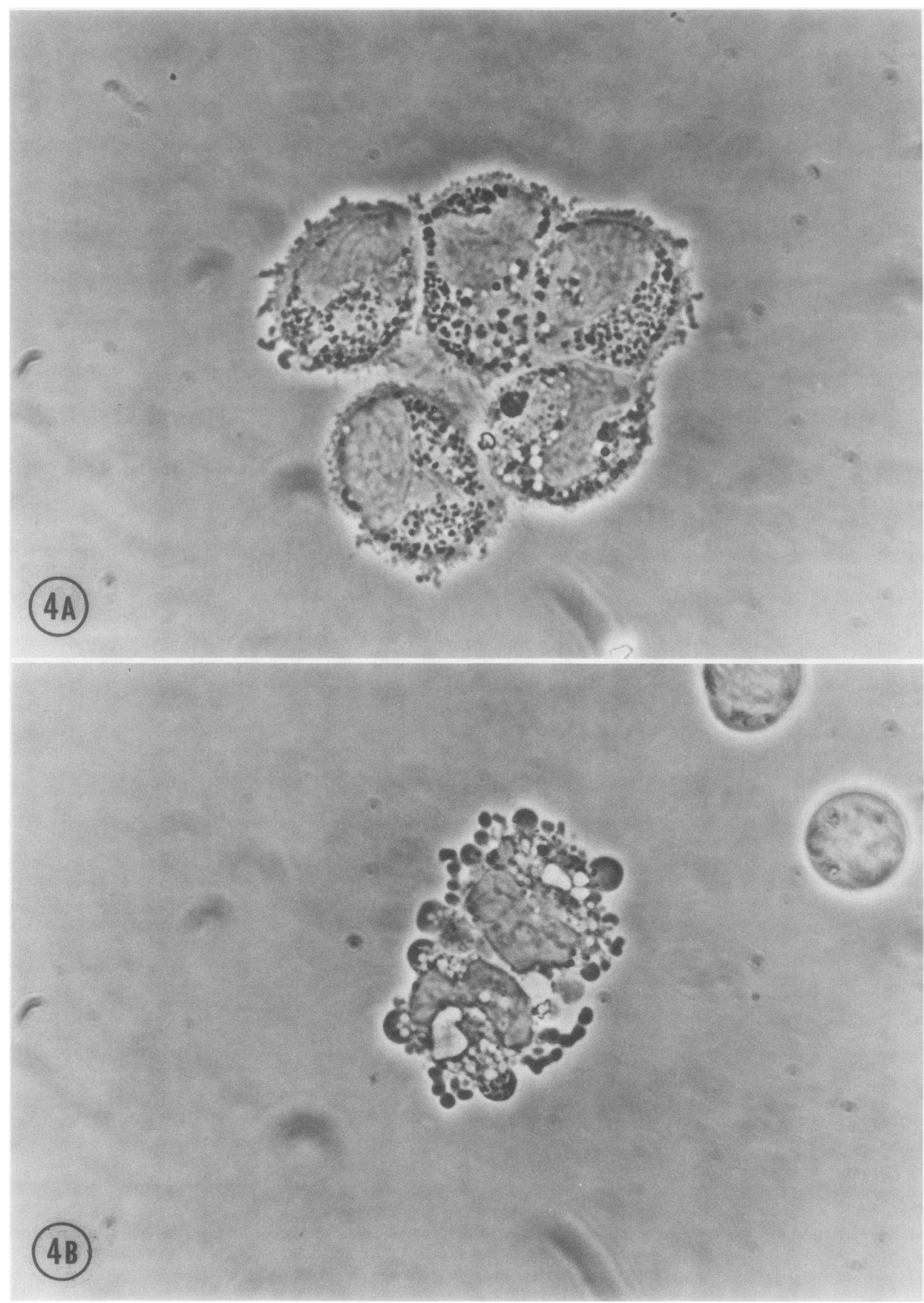


of the cells were positively stained. After $72 \mathrm{~h}$ the cells exhibited even more reaction product, and more than $90 \%$ of the cells were positively stained. In addition, the specific activity of acid phosphatase measured in cell extracts after $72 \mathrm{~h}$ was greater than that observed for cells before cultivation (Fig. 2).

The specific activity of ADA increased two- to ninefold in the transforming monocytes (Fig. 2). The increase could be detected as early as $3-4 \mathrm{~h}$ and reached a maximum after 16-24 h. There was no increase in the specific activity of the purine salvage pathway enzymes, adenine phosphoribosyltransferase, hypoxanthineguanine phosphoribosyltransferase, or adenosine kinase (Fig. 2).

To determine whether the increase in ADA activity during maturation was due to the loss of an inhibitor or the appearance of an activator, a mixing experiment was performed. When extracts from monocytes before and after cultivation were mixed, the ADA activity equaled the arithmetic sum of the activities found in the individual extracts (Table I).

Since a medium containing fetal calf serum exhibits low levels $(<0.01 \mu \mathrm{mol} / \mathrm{h}$ per $\mathrm{mg}$ protein) of ADA activity even after the heat treatment, we sought to exclude the possibility that the increase in ADA activity in the cells was due to ingestion of the enzyme from the medium. The cells were therefore cultured in medium devoid of serum. The viability of such cells started to decrease on the 2nd day in culture, however an increase in ADA specific activity comparable to that of control cultures was observed (Table II).

Molecular forms. The molecular forms of ADA were compared in extracts from monocytes before and after cultivation. Sucrose density ultracentrifugation of extracts from monocytes processed immediately after isolation revealed the presence of two forms of $\mathrm{ADA}$ with s20,w values of 3.2 and 7.4, respectively (molecular weights of approximately 30,000 and 110,000 ). After $24 \mathrm{~h}$ in culture, the activity of the smaller molecular species increased (Fig. 3) and after $40 \mathrm{~h}$, only the small form was found in the extracts.

Effect of puromycin. Table III summarizes the effect of puromycin on cultured monocytes. After $20 \mathrm{~h}$ in culture, puromycin had reduced the incorporation of $\left[{ }^{3} \mathrm{H}\right]$ leucine by $60 \%$. The increase in ADA specific activity was blocked, and the morphological changes normally observed during maturation did not occur.

Effect of $A D A$ inhibitor. When $0.3 \mathrm{mM}$ EHNA was added to cell extracts, ADA activity was com- pletely inhibited while the activities of adenosine kinase, adenine phosphoribosyltransferase, hypoxanthine-guanine phosphoribosyltransferase, or acid phosphatase were not affected (Table IV). At this concentration of EHNA $(0.3 \mathrm{mM})$, the normal morphological changes observed in maturing monocytes did not occur. During the first 3 days in culture in the presence of this inhibitor, there was no apparent increase in the cytoplasm, and only lipid droplets, numerous vacuoles, and a few phase-dense granules could be seen (Fig. 4). By the 3rd day in culture $50 \%$ of the cells had died. When EHNA was removed after $24 \mathrm{~h}$ in culture, the monocytes underwent morphological changes that could not be distinguished from those observed in untreated cultures. When added during the 2 nd day in culture, EHNA blocked the maturation of only $10-40 \%$ of the monocytes. However, most of the cells contained numerous vacuoles.

The effect of this potent and apparently specific inhibitor of ADA (27) ${ }^{2}$ on monocyte maturation and viability is summarized in Table V. In the absence of EHNA the addition of adenosine $(1 \mathrm{mM})$ had no apparent effect on monocyte maturation in culture as judged by morphological characteristics or the increase in acid phosphatase activity. Adenosine also had no discernible effect when the fetal calf serum was replaced with horse serum which is said to lack any detectable ADA activity (28), thereby minimizing the possibility that the excess adenosine may be deaminated by the low levels of ADA activity in the medium. However, when adenosine was added concomitantly with EHNA $(75 \mu \mathrm{M})$, most of the cells were dead within 3 days. This effect of adenosine was not prevented by the addition of $1 \mathrm{mM}$ uridine and is thus unlikely to be due to pyrimidine starvation as described by Green and Chan (6) and Ishii and Green (28).

In the presence of low concentrations of EHNA $(75 \mu \mathrm{M})$ without the addition of adenosine, the cultured monocytes underwent morphological changes which could not be distinguished from those observed in the absence of the inhibitor. However, the specific activity of acid phosphatase did not increase.

\section{DISCUSSION}

A causal relationship between ADA activity and normal immune function is suggested by the finding of combined immunodeficiency in patients with a deficiency of the enzyme. In view of the central role macrophages play in the immune response, their maturation from

FIgURE 4 The effect of an ADA inhibitor (EHNA) on monocyte maturation. Phase-contrast micrographs of unfixed preparations were made after $48 \mathrm{~h}$ in culture. (A) Control, monocytes cultured in RPMI 1640 containing $30 \%$ heat inactivated fetal calf serum. (B) Monocytes cultured in the above media containing $0.3 \mathrm{mM}$ EHNA. In comparison to the control, these cells possess less cytoplasm which contains lipid droplets, numerous vacuoles, and only a few phasedense granules. 
monocytes is probably essential for normal function of the immune system. Thus, we studied the role of ADA in the maturation of monocytes to macrophages in vitro.

When cultivated in vitro, monocytes underwent a sequence of morphological and biochemical alterations, after which they attained characteristics of typically mature macrophages. This maturation was accompanied by increasing numbers of lysosomes, which appeared as phase-dense granules in the enlarged cytoplasm, and by a rise in the specific activity of the lysosomal enzyme, acid phosphatase. These observations were in accordance with the results reported by Bennett and Cohn (16) who described in detail the morphological and functional changes the monocytes undergo in culture, and the accompanying biochemical alterations which include an increase in the activity of lysosomal enzymes.

ADA specific activity increased two- to ninefold during the early stages of monocyte to macrophage transition. This increase in activity was blocked by puromycin. While monocyte extracts contained two forms of ADA, the increase in ADA specific activity in macrophages correlated with an increase in the activity of only the smaller molecular species. The increase in ADA activity during monocyte maturation could be attributed neither to loss of an inhibitor nor development of an activator of the enzyme; when extracts from monocytes and macrophages were mixed, the ADA activity was equal to the arithmetic sum of the activities found in the individual extracts. The above results are consistent with the possibility that the increase in ADA activity might be due to a de novo synthesis of the enzyme. However, the possibility that the increase is a result of activation rather than synthesis cannot be excluded.

The increase in ADA activity is unlikely to be a nonspecific reflection of nucleic acid synthesis, for while the activity of this enzyme increases in the nondividing monocytes, it does not increase in phytohemagglutininstimulated lymphocytes during their transformation to actively dividing lymphoblasts (29). Furthermore the increase in ADA activity in monocytes could not be attributed to a general increase in all enzymes involved in purine metabolism since no increase was found in the specific activity of another enzyme involved in the adenosine cycle, adenosine kinase, and in two other enzymes participating in the purine salvage pathway, hypoxanthine-guanine phosphoribosyltransferase, and adenine phosphoribosyltransferase. Finally, ADA does not appear to be associated with lysosomes (M. B. Van der Weyden, unpublished data); thus the increase in activity is not a reflection of the increased number of lysosomes.

Whatever the mechanism, the rapid and prominent increase in ADA activity triggered with the monocyte to macrophage transition suggests that ADA could have an important role in this process. This increase in ADA activity might be required to provide the cell with a mechanism for detoxifying adenosine. The effect of excess adenosine on cell viability and function has now been reported in several different cell types $(6,7$, 28, 30, 31). Green and Chan (6) have reported the toxicity of adenosine when added to established cultures of fibroblasts or lymphoid cells. They found that in the presence of $0.01-0.1 \mathrm{mM}$ adenosine the cells die as a result of pyrimidine starvation. Lower concentrations of adenosine inhibit cell growth. The toxic effects were prevented by exogenous pyrimidine nucleotides such as uridine.

Normal monocytes are protected against the toxicity of excess adenosine even when added to the cultures at a concentration as high as $1 \mathrm{mM}$. This protection probably requires normal ADA activity in the cells, since inhibition of ADA by a specific inhibitor rendered the adenosine toxic and resulted in cytolysis. The ability of adenosine to cause cytolysis in monocyte cultures seems to be unrelated to the pyrimidine starvation described by Green and Chan (6) since the effect was not prevented by the presence of excess uridine.

The studies with the ADA inhibitor, EHNA, suggest that $\mathrm{ADA}$ may be required for normal maturation of the monocytes. Low concentrations of the inhibitor prevented the increase in acid phosphatase specific activity. At higher concentrations, morphological changes of the cells associated with the maturation process were retarded but could be restored when EHNA was removed after the 1st day in culture. The rapid increase in the specific activity of ADA, which reaches its maximum during the 1st day in culture, suggests the involvement of ADA in the early stages of the maturation. This is further supported by the observation that the ADA inhibitor blocks the maturation of only a relatively small percentage of the monocytes when added to the cultures on the 2 nd day.

Both Green and Chan (6) and Wolberg et al. (7) suggested that the accumulation of adenosine in lymphoid cells may contribute to the defective immune system associated with ADA deficiency. Our observations indicate that ADA might be important for normal macrophage function and that the abnormality of both humoral and cellular immunity in patients with ADA deficiency could be due, at least in part, to macrophage dysfunction.

\section{ACKNOWLEDGMENTS}

We gratefully acknowledge the advice and criticism of $\mathrm{Dr}$. E. W. Holmes during the course of these studies.

This work was supported in part by U. S. Public Health Service grants AM 14362, ROI DEO 3738-03, a National 
Cancer Institute Contract NOICP 33313, an Arthritis Foundation Center Grant, and an Arthritis and Metabolism Diseases Institutional Training Grant IT32-AM 07015-01.

\section{REFERENCES}

1. Giblett, E. L., J. E. Anderson, F. Cohen, B. Pollara, and H. J. Meuwissen. 1972. Adenosine-deaminase deficiency in two patients with severely impaired cellular immunity. Lancet. 2: 1067-1069.

2. Dissing, J., and B. Knudsen. 1972. Adenosine-deaminase deficiency and combined immunodeficiency syndrome. Lancet. 2 : 1316.

3. Spencer, N., D. A. Hopkinson, and H. Harris. 1968. Adenosine deaminase polymorphism in man. Ann. Hum. Genet. 32: 9-14.

4. Meuwissen, H. J., R. J. Pickering, E. C. Moore, and B. Pollara. 1975. Impairment of adenosine deaminase activity in combined immunological deficiency disease. In Combined Immunodeficiency Disease and Adenosine Deaminase Deficiency. A Molecular Defect. H. J. Meuwissen, R. J. Pickering, B. Pollara, and I. H. Porter, editors. Academic Press, Inc., New York. 73-83.

5. Green, H., and K. Ishii. 1972. On the existence of a guanine nucleotide trap. The role of adenosine kinase and a possible cause of excessive purine production in mammalian cells. J. Cell Sci. 11: 173-177.

6. Green, H., and T-S. Chan. 1973. Pyrimidine starvation induced by adenosine in fibroblasts and lymphoid cells. Role of adenosine deaminase. Science (Wash. D. C.). 182: 836-837.

7. Wolberg, G., T. P. Zimmerman, K. Hiemstra, M. Winston, and L-C. Chu. 1975. Adenosine inhibition of lymphocyte-mediated cytolysis. Possible role of cyclic adenosine monophosphate. Science (Wash. D. C.). 187: 957959.

8. Cohn, Z. A. 1968. The structure and function of monocytes and macrophages. Adv. Immunol. 9: 163-214.

9. Unanue, E. R. 1972. The regulatory role of macrophages in antigenic stimulation. Adv. Immunol. 15: 95-165.

10. Nelson, D. S. 1969. Macrophages and Immunity. NorthHolland Publishing Co. Amsterdam. 335 pp.

11. Meuret, G., and G. Hoffmann. 1973. Monocyte kinetic studies in normal and disease states. Br. J. Haematol. 24: 275-285.

12. Spector, W. G., and D. A. Willoughby. 1963. The inflammatory response. Bacteriol. Rev. 27 : 117-154.

13. Ebert, R. H., and H. W. Florey. 1939. The extravascular development of the monocyte observed in vivo. $\mathrm{Br}$. J. Exp. Pathol. 20 : 342-356.

14. Eccles, S. A., and P. Alexander. 1974. Macrophage content of tumours in relation to metastatic spread and host immune reaction. Nature (Lond.). 250: 667-669.

15. Nossal, G. J. V., and G. L. Ada. 1971. Antigens, Lymphoid Cells, and the Immune Response. Academic Press, Inc., New York. 324 pp.

16. Bennett, W. E., and Z. A. Cohn. 1966. The isolation and selected properties of blood monocytes. J. Exp. Mcd. 123: 145-159.

17. Brodersen, M. P., and C. P. Burns. 1973. The separation of human monocytes from blood including biochemical observations. Proc. Soc. Exp. Biol. Med. 144: 941-944.

18. Van der Weyden, M. B., R. H. Buckley, and W. N. Kelley. 1974. Molecular form of adenosine deaminase in severe combined immunodeficiency. Biochem. Biophys. Res. Commun. 57 : 590-595.

19. Kelley, W. N., F. M. Rosenbloom, J. F. Henderson, and J. E. Seegmiller. 1967. A specific enzyme defect in gout associated with overproduction of uric acid. Proc. Natl. Acad. Sci. U. S. A. 57: 1735-1739.

20. Lindberg, B., H. Klenow, and K. Hansen. 1967. Some properties of partially purified mammalian adenosine kinase. J. Biol. Chem. 242: 350-356.

21. Vaes, G. 1968. On the mechanisms of bone resorption. The action of parathyroid hormone on the excretion and synthesis of lysosomal enzymes and on the extracellular release of acid by bone cells. J. Cell Biol. 39: 676-697.

22. Rosenszajn, L., G. Marshak, and P. Efrati. 1963. Acid phosphatase activity in normal human blood and bone marrow cells as demonstrated by the Azo dye method. Acta Haematol. (Basel). 30: 310-316.

23. Lowry, O. H., N. J. Rosenbrough, A. L. Farr, and R. J. Randall. 1951. Protein measurement with the Folin phenol reagent. J. Biol. Chem. 193: 265-275.

24. Rej, R., and A. H. Richards. 1974. Interference by Tris buffer in the estimation of protein by the Lowry procedure. Anal. Biochem. 62: 240-247.

25. Holmes, E. W., J. B. Wyngaarden, and W. N. Kelley. 1973. Human glutamine phosphoribosylpyrophosphate amidotransferase. Two molecular forms interconvertible by purine ribonucleotides and phosphoribosylpyrophosphate. J. Biol. Chem. 248: 6035-6040.

26. McCarty, K. S., D. Stafford, and O. Brown. 1968. Resolution and fractionation of macromolecules by isokinetic sucrose density gradient sedimentation. Anal. Biochem. 24 : 314-329.

27. Schaeffer, H. J., and C. F. Schwender. 1974. Enzyme inhibitors. 26. Bridging hydrophobic and hydrophilic regions on adenosine deaminase with some $9-(2-\mathrm{Hy}-$ droxy-3-alkyl)adenines. J. Mcd. Chem. 17: 6-8.

28. Ishii, K., and H. Green. 1973. Lethality of adenosine for cultured mammalian cells by interference with pyrimidine biosynthesis. J. Cell Sci. 13: 429-439.

29. Hirschhorn, R., and V. Levytska. 1974. Alterations in isozymes of adenosine deaminase during stimulation of human peripheral blood lymphocytes. Cell Immunol. 12: 387-395.

30. Manohar, S. V., M. H. Lerner, and D. Rubinstein. 1968. The metabolism of the erythrocyte. XVIII. Inhibition of nucleotide synthesis in human erythrocytes by adenosine. Can. J. Biochem. 46: 445-450.

31. Fain, J. N., and P. B. Wieser. 1975. Effects of adenosine deaminase on cyclic adenosine monophosphate accumulation, lipolysis, and glucose metabolism of fat cells. $J$. Biol. Chem. 250: 1027-1034. 